\title{
Thoracoabdominal mobility evaluation by photogrammetry in newborns after expiratory flow increase technique
}

\author{
Avaliação da mobilidade toracoabdominal por fotogrametria em \\ recém-nascidos após a técnica de aumento do fluxo expiratório
}

\author{
Júlia Isabel de Araújo Guerra ${ }^{[a]}$, Danilo Alves Pinto Nagem ${ }^{[b]}$, Cristiane Aparecida Moran ${ }^{[c]}$, \\ Valéria Lidyanne Souza Gomes ${ }^{[\mathrm{a}]}$, Juliana Macedo Campelo de Carvalho ${ }^{[\mathrm{a}]}$, Silvana Alves Pereira ${ }^{[\mathrm{a}]^{*}}$
}

[a] Universidade Federal do Rio Grande do Norte (UFRN), Santa Cruz, RN, Brazil

[b] Universidade Federal do Rio Grande do Norte (UFRN), Natal, RN, Brazil

[c] Universidade Federal de São Paulo (Unifesp), São Paulo, SP, Brazil

\begin{abstract}
Introduction: Expiratory flow increase is a maneuver of respiratory physical therapy that promotes flow direction to the upper airways however, when applied in newborns, it may result in changes of thoracoabdominal mobility. Objective: To evaluate the thoracoabdominal mobility by photogrammetry in newborns after expiratory flow increase technique. Methods: Experimental blind study performed with newborns in supine position on a support table with upper limbs flexed, abducted and externally rotated and hip flexed at $110^{\circ}$. Adhesive markers were allocated for geometric delimitation of the thoracoabdominal compartment and expiratory flow increase technique was performed for 5 minutes with the therapist's hands on the thorax and abdomen. Newborns were filmed before and after the maneuver and the frames were analyzed in AutoCAD ${ }^{\circledR}$ software by a blinded investigator at the time of the procedure. The largest and the smallest thoracoabdominal area were expressed in $\mathrm{cm}^{2}$ and the mean values were compared between two moments (pre and post maneuver) by paired t test. Results: Twenty newborns with a mean age of 39 weeks were included. Before the maneuver, thoracoabdominal area was $56.1 \mathrm{~cm}^{2}$ during expiration and $59.7 \mathrm{~cm}^{2}$ during inspiration, and after the maneuver the value was $56.2 \mathrm{~cm}^{2}$ during expiration and $59.8 \mathrm{~cm}^{2}$ during inspiration,
\end{abstract}

* JIAG: BS, email: juguerra94@gmail.com DAPN: PhD, email: danilo.nagem@gmail.com CAM: PhD, email: crismoran@uol.com.br VLSG: BS, email: valerialidyanne@yahoo.com.br JMCC: BS, email: julianacampelo0824@hotmail.com SAP: PhD, email: apsilvana@gmail.com 
with no statistical difference between before and after ( $p=0.97, p=0.92$, respectively). Conclusion: Results demonstrate that expiratory flow increase technique does not seem to change thoracoabdominal mobility of healthy newborns.

Keywords: Respiratory Mechanics. Photogrammetry. Newborn. Modalities of Physical Therapy. Physiotherapy.

Resumo

Introdução: $O$ aumento do fluxo expiratório é uma manobra da fisioterapia respiratória que promove um direcionamento do fluxo para as vias aéreas superiores, entretanto, quando aplicada em recém-nascidos, pode resultar em uma variação da mobilidade toracoabdominal. Objetivo: Avaliar a mobilidade toracoabdominal pela fotogrametria em recém-nascidos após a manobra de aumento do fluxo expiratório. Métodos: Estudo experimental, cego, realizado com os recém-nascidos posicionados em supino sobre uma bancada de apoio com o membro superior em flexão, abdução e rotação externa e quadril flexionado a $110^{\circ}$. Foram alocados marcadores adesivos para a delimitação geométrica do compartimento toracoabdominal e o aumento do fluxo expiratório foi realizado por 5 minutos com as mãos do terapeuta sobre o tórax e abdome. Os recém-nascidos foram filmados pré e pós-manobra e os fotogramas foram analisados no software AutoCAD por um pesquisador cego ao momento do experimento. A maior e a menor área toracoabdominal foram expressas em $\mathrm{cm}^{2}$ e os valores médios foram comparados entre os dois momentos (pré e pós manobra) pelo Teste t pareado. Resultados: Foram incluídos 20 recém-nascidos com idade média de 39 semanas. Antes da manobra a área toracoabdominal foi $56,1 \mathrm{~cm} 2$ durante a expiração e $59,7 \mathrm{~cm}^{2}$ na inspiração e após a manobra o valor foi $56,2 \mathrm{~cm}^{2} \mathrm{du}$ rante a expiração e $59,8 \mathrm{~cm}^{2}$ durante a inspiração, sem diferença estatística entre o antes e o depois $(p=0,97$, $p=0,92$, respectivamente). Conclusão: Os resultados deste estudo demonstram que a técnica de aumento do fluxo expiratório parece não alterar a mobilidade toracoabdominal de recém-nascidos saudáveis.

Palavras-chave: Mecânica Respiratória. Fotogrametria. Recém-nascido. Modalidades de Fisioterapia. Fisioterapia.

\section{Introduction}

In newborns, changes in respiratory muscle, muscle synergy and ribcage are slow and depend on several factors, from intrauterine bulbar center development to adaptations of pulmonary morphology of extrauterine life $(1-3)$. However, the knowledge of neonatal pulmonary physiology and the changes that occur in its intra and extrauterine development are fundamental for the management during the evaluation of respiratory physical therapy.

This is because respiratory physical therapy encompasses a large number of maneuvers that aid pulmonary recovery, such as expiratory flow increase technique, which modifies the inspiratory and expiratory variables, in order to promote flow guided to the upper airways and, when applied in newborns, it may result in thoracoabdominal mobility changes $(4,5)$.
As part of this assessment, the development of computerized devices for the measurement of respiratory mechanics has enabled to evaluate mobility in the most diverse clinical situations and age groups, however, these systems are commonly restricted to high cost research centers and most of them do not apply to neonatology (6).

Among these systems, we highlight: $\mathrm{PCLAB}^{\circledR}$ software - a precursor in the software development with medical applicability, developed at Mcgill University, Canada, in 1994, which the composition of final data consists of electrical signal graphics (7); Inductance plethysmography, considered a gold standard for pulmonary evaluation by means of volume change between the ribcage and abdominal compartment (8); and Optoelectronic Plethysmography (OEP), a non-invasive evaluation method that allows the indirect quantification of pulmonary volumes (9). 
Unlike the previously mentioned systems, biophotogrammetry stands out as a versatile and easily adaptable mechanism for several areas (10). Its use allows the geometric delimitation of thoracoabdominal compartments from the extension of the thoracic wall and its thoracic and abdominal subcompartments $(6,10,11)$. As an ascending technique, it has two ways of evaluation, photogrammetry and videogrammetry, that evaluate kinematics of body movements by a set of photos and video acquisition, respectively, and it may be used in two-dimensional (2D) or three-dimensional (3D) evaluation $(12,13)$.

Although there is already specific software for biophotogrammetry, such as $\mathrm{SAPO}^{\circledR}$, its application is focused on postural analysis and, in spite of respiratory analysis, records are analyzed by software such as Coreldraw ${ }^{\circledR}$ and AutoCAD ${ }^{\circledR}$ (14). However, this concept was recently applied for the newborns' evaluation of respiratory mechanics (6).

Although expiratory flow increase technique is a widely used technique in newborns, it has not been studied in such large proportion in this population $(4,15,16)$. The few studies do not show clear results regarding the effect of this technique on thoracoabdominal kinematics in newborns. In this perspective, the objetive of this study is to evaluate thoracoabdominal mobility by photogrammetry in newborns after expiratory flow increase technique.

\section{Methods}

This is an experimental study carried out into the housing unit of the Ana Bezerra University Hospital (HUAB). The study was approved by the Research Ethics Committee of FACISA/UFRN (protocol number 80203/2014), in compliance with resolution 466/2012 of the National Health Council. All newborns included in the study had a free and informed consent form signed by their legal responsible person.

Sample recruitment was performed in a nonprobabilistic way, by convenience from HUAB hospitalizations during the study period (from March to August, 2015). The study included 22 newborns with gestational ages between 37 and 41 weeks of both sexes, up to 72 hours of age, in ambient air, who were awake (stage 4 of Brazelton scale) (17). Newborns with congenital malformation, genetic syndrome, heart failure and respiratory diseases were excluded from the study.
Procedures for data collection

In order to capture the images, newborns were placed in supine position on a support table with the surface covered with a hypoallergenic and disposable EVA sheet of approximately $50 \mathrm{~cm}$ in length and 0.2 mm thick. After positioning, adhesive markers were allocated to the following points: [1] anterior superior iliac spines and [2] level of the jugular notch of the sternal manubrium, projected laterally. These references served as an anchor for the geometric delimitation of the thoracoabdominal compartment in the acquired images during photogrammetry (Figure 1). The final tracing was an adaptation to the lying posture of the model used by Ricieri and Rosário Filho (10) and reported in the study by Oliveira HB et.al (6). After adjusting the markers, newborns were positioned with the upper limbs flexed, abducted and externally rotated, hip flexed at $110^{\circ}$ and maximal exposure of thoracic region (Figure 1).

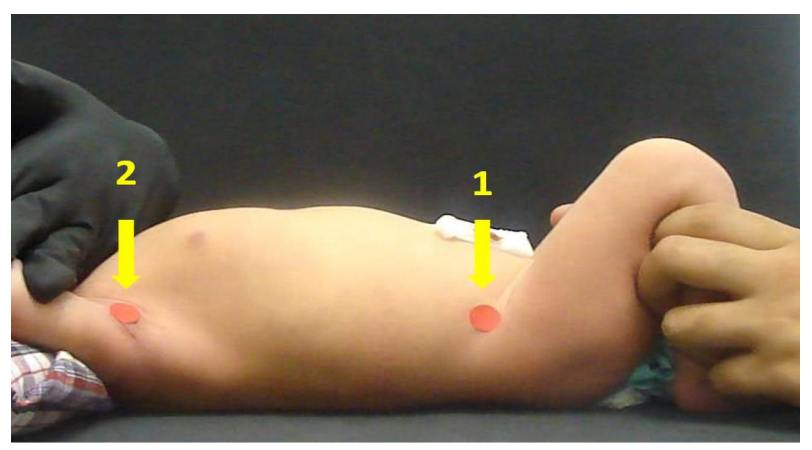

Figure $\mathbf{1}$ - Newborn positioning during the experiment and indication of the markers for delimitation of thoracoabdominal compartment, where: (1) anterior superior iliac spines and (2) level of the jugular notch of the sternal manubrium, projected laterally.

Images acquisition

A digital Sony Cyber-shot DSC-H20 ${ }^{\circledR}$ camera, with 10.1 Megapixels, positioned $30 \mathrm{~cm}$ away from the newborn, was used on a tripod with a fixed height of 1 meter. After adjusting the markers, the newborn was filmed for 60 seconds before and after expiratory flow increase technique.

The technique was applied by a single investigator (JIAG) and all evaluations consisted of synchronous and slow thoracoabdominal movements generated by the investigator's hands during expiratory time. 
One hand was placed over the thorax and the other over the abdomen. With the thoracic hand, an oblique pressure was applied from top to bottom and from front to back towards the abdominal hand during expiration. The technique was performed for 5 minutes with 15-second intervals between them (4).

\section{Interpretation of images}

Each experiment generated 80 frames in 120 seconds and all were analyzed through AutoCAD ${ }^{\circledR}$ software, by a second investigator blinded to the study. This investigator did not identify whether the frames represented pre or post expiratory flow increase technique. The extension of thoracoabdominal compartment was delimited, superiorly, from the level of the jugular notch of the sternum, and inferiorly, to the anterior superior iliac spine. Mobility was expressed in $\mathrm{cm}^{2}$, by the lateral area of this compartment (8) (Figure 1). Frames with the largest and the smallest area were analyzed as inspiratory and expiratory movement, respectively.

\section{Data analysis}

The 1600 frames (80 frames x 20 newborns) were submitted to statistical analysis in the software Statistical Package for the Social Sciences (SPSS) ${ }^{\circledR}$, version 20.0 in the following steps: KolmogorovSmirnov test to verify data distribution; use of parametric or non-parametric inferential tests to compare descriptive characteristics of each data group; paired t test to compare differences between the means of thoracoabdominal area, pre and post technique; significance for the results was considered $\mathrm{p}<0.05$.

\section{Results}

From 22 newborns included in the study, 20 were included and two newborns were excluded during images interpretation due to poor frame quality. From the 20 newborns in the study, 12 were female and 9 were born by $\mathrm{C}$-section. Table 1 shows descriptive sample data $(n=20)$.
Table 1 - Characteristics of the studied population $(n=20)$

\begin{tabular}{lccccc}
\hline VARIABLES & \multicolumn{5}{c}{ MEASURES } \\
\hline & Mean & Median & Min. & Max. & SD \\
\hline GA (weeks) & 39 & 39 & 37 & 41 & 2 \\
Weight (grams) & 3345 & 3345 & 2540 & 3930 & 400.18 \\
Apgar 1min & 9 & 9 & 8 & 9 & 0.75 \\
Apgar 5min & 9 & 9 & 8 & 10 & 0.36 \\
CP (cm) & 35 & 35 & 33 & 37 & 1.45 \\
Length (cm) & 48.7 & 49 & 45 & 51 & 1.92 \\
RR (bpm) & 57 & 57 & 42 & 78 & 9.90 \\
Life hours & 22.7 & 22.5 & 3 & 45 & 9.81 \\
\hline
\end{tabular}

Note: GA: gestational age; min: minute; CP: cephalic perimeter; $\mathrm{cm}$ : centimeter; RR: respiratory rate; bpm: breaths per minute.

Before expiratory flow increase technique, thoracoabdominal area was $56.1 \mathrm{~cm}^{2}$ during expiration and $59.7 \mathrm{~cm}^{2}$ during inspiration, and after the technique the value was $56.2 \mathrm{~cm}^{2}$ during expiration and 59.8 $\mathrm{cm}^{2}$ during inspiration. Figure 2 shows that there is no significant statistical difference in the thoracoabdominal area, before and after the technique, throughout the respiratory cycle.

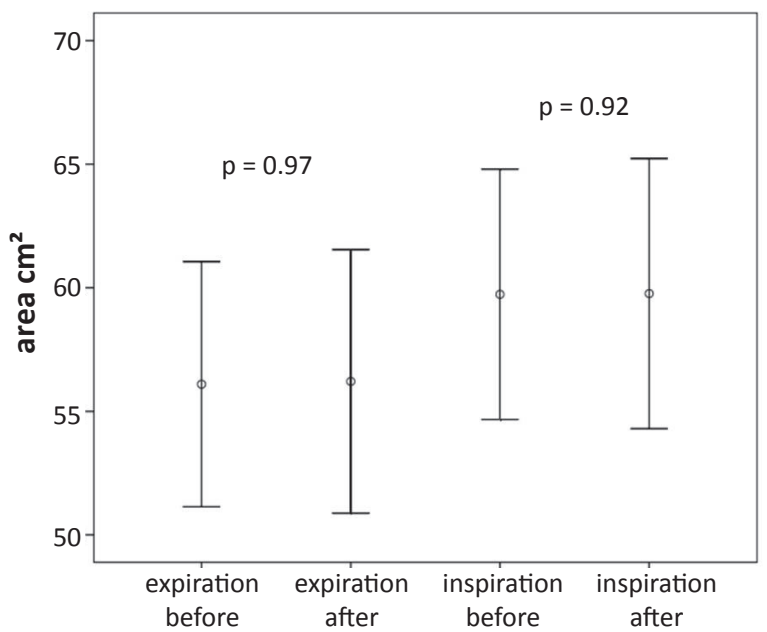

Figure 2 - Means comparison of thoracoabdominal area, before and after expiratory flow increase technique throughout respiratory cycle (inspiration and expiration). The figure shows that there is no significant statistical difference $(p<$ 0.05 and paired t-test). 


\section{Discussion}

The study demonstrated that the proposed geometric model for the evaluation of thoracoabdominal mobility was effective in differentiating the delimitation of thoracoabdominal area of newborns at the bedside, and in this evaluation, it was observed that expiratory flow increase technique does not change thoracoabdominal mobility throughout respiratory cycle.

Fontoura (18) described that the main objective of expiratory flow increase technique is to eliminate air from the lungs at high speed, and with the mechanic technique procedure, it is not expected to have the increase of the lung area as effect, since the physiology of the technique involves pulmonary emptying process.

It was expected that the process of pulmonary emptying would cause decrease in thoracoabdominal area, which was not found in our results.

Although expiratory flow increase technique is a widely used technique in all age groups, with a strong use in hospital neonatology (19), there is a great lack of studies that stipulate its effects on thoracoabdominal mechanics (20). On the other hand, there are other studies $(4,21,16,22-25)$ that evaluate the technique effects on vital data, such as respiratory rate, heart rate and peripheral oxygen saturation, and these data may corroborate with this study findings.

In the study by Souza and Moran (4) effects of vibrocompression and expiratory flow increase technique were compared in preterm newborns hospitalized for respiratory distress syndrome, and each technique was applied for 5 minutes. In this study, no differences were observed in clinical responses of vibration and expiratory flow increase technique, since the physiological and clinical parameters evaluated (respiratory rate, heart rate, peripheral oxygen saturation and Silverman Anderson score) did not change significantly, considering, according to the authors, that there is a clinical stability of the newborns submitted to them, when the main objective is bronchial hygiene.

In this sense, Luisi (21) reported in his review on viral bronchiolitis, that French studies emphasize the expiratory flow increase technique due to its effectiveness without major systemic changes (21 23), and vibrocompression, tapotage and postural drainage techniques do not present benefits on this disease progression.

Contrasting these claims, Gardengui et al. (23), in a prospective and experimental study with a sample of 30 infants under 8 months old, compared the effects of expiratory flow increase technique, , vibrocompression and postural drainage on cardiorespiratory parameters (respiratory rate, heart rate and peripheral oxygen saturation) in patients with viral bronchiolitis, and showed that there is a rise in respiratory work represented by increased respiratory and heart rates after expiratory flow increase technique. In addition, they did not find significant effects on peripheral oxygen saturation in their study.

Corroborating with Gardengui et al. (23) findings, Diniz et al. (24), using methods similar to this study, which evaluated the effects of thoracic compression respiratory maneuvers on hemodynamic and respiratory signs of infants with pulmonary atelectasis, observed that chest compression techniques promote increased respiratory rate, signs of respiratory discomfort and decreased peripheral oxygen saturation, once again reinforcing the clinical instability of compressive techniques application and confronting the study of Souza and Moran (16).

An important mechanical problem that directly influences the use of compressive techniques is that in newborns, the process of passive expiration occurs in very low volumes due to resistive properties of the pulmonary parenchyma, especially regarding alveolar surface tension, that is, techniques of pulmonary emptying may increase the risk of alveolar collapse (22). This neonatal characteristic may occasionally contraindicate this technique in spontaneously breathing (20), and it may also justify the need for objective assessments, at the bedside, of thoracoabdominal mobility during respiratory physical therapy maneuvers, such as the one presented in this study.

The I Brazilian Recommendation of Respiratory Physical Therapy in Pediatric and Neonatal ICU (26) suggests that the application of expiratory flow increase technique should be done slowly for newborns; aiming to train exclusively flow direction, without thorax compression, with intervention at least once a day, from 5 to 10 minutes, and these characteristics may have been an interferential factor in the results reported in this study, since they considered during the experiment design.

The analysis method of thoracoabdominal mobility proposed in this study reached the objective of evaluating thoracoabdominal compartment in newborns and it was able to observe changes of thoracoabdominal area before and after expiratory flow increase technique. The method was effective in differentiating the 
delimitation changes of thoracoabdominal region and it has proved to be a useful tool in the evaluation of patients who do not voluntarily control respiratory rate and synergy of muscle activity during breathing.

Ricieri (11) reports that the use of photogrammetry for the analysis of respiratory movement allows to establish evidence of the volume-movement relationship and this information may be used to infer respiratory mechanical behaviors of relevant clinical utility for respiratory physical therapy, which can be observed in this study. Although this study presents a 2D model, results demonstrate that the methodology was effective to monitor neonatal respiratory kinematics during the application of a respiratory physical therapy technique.

However, some limitations must be considered. The methodology described in this experiment proved to be effective for the acquisition of measurements and numerical information used in neonatal clinical applications, to do so, each frame was individually processed in AutoCAD ${ }^{\circledR}$. Although this method is effective, it is time-consuming, as each frame takes from 10 to 25 minutes to be processed. To be sure of the peak and the basis of the respiratory movement, it was necessary to analyze all generated frames, which resulted in at least 13 hours of work for each newborn in this study. An algorithm capable of doing this task automatically, would be a great tool, once it would decrease the working time. Vital signs and general characteristics of birth after the technique were also not evaluated, which restricts comparison with results obtained in other studies $(19,23,27-30)$. The hypothesis raised with our results is that the evaluation of vital signs and general birth characteristics (such as birth weight and gestational age) could be correlated with thoracoabdominal mobility and thus support our hypothesis that expiratory flow increase technique does not seem to change thoracoabdominal mobility of newborns.

\section{Conclusion}

The results of this study demonstrate that expiratory flow increase technique, when evaluated by biophotogrammetry, in healthy newborns, does not seem to change thoracoabdominal mobility, which may reinforce their indication for newborns. However, new studies are needed with larger samples and different newborn characteristics to reach more definitive conclusions.

\section{References}

1. Bavis RW, Mitchell GS. Long-term effects of the perinatal environment on respiratory control. J Appl Physiol. 2008;104(4):1220-9.

2. Bavis RW, Powell FL, Bradford A, Hsia CCW, Peltonen JE, Soliz J, et al. Respiratory plasticity in response to changes in oxygen supply and demand. Integr Comp Biol. 2007;47(4):532-51.

3. Mitchell GS, Johnson SM. Plasticity in Respiratory Motor Control Invited Review: Neuroplasticity in respiratory motor control. J Appl Physiol. 2003;94(1):358-74.

4. Souza JAQ, Moran CA. Fisioterapia respiratória em recém-nascidos pré-termo: ensaio clínico randomizado. Pediatr Mod. 2013;49(11):434-8.

5. Pedrini A, Gonçalves MA, Leal BE, Yamaguti WPS, Paulin E. Comparação entre as medidas de cirtometria toraco-abdominal realizadas em decúbito dorsal e ortostatismo. Fisioter Pesq. 2013;20(4):373-8.

6. Oliveira HB, Pereira AS, Vale BEC, Pinto DN. Image recognition system for evaluating thoracoabdominal movements in newborns. R-BITS. 2016;6(1):1-10.

7. Ramos JR, Odeh CSA, Lopes JMA. Mecânica Pulmonar do recém-nascido normal. J Pediatr. 1994;70(3):163-6.

8. Barbosa RCC, Carvalho CRF, Moryia HT. Pletismografia respiratória por indutância: estudo comparativo entre calibração por manobra de isovolume e calibração qualitativa diagnóstica em voluntários saudáveis avaliados em diferentes posturas. J Bras Pneumol. 2012;38(2):194-201.

9. Myrrha MAC, Vieira DSR, Moraes KS, Lage SM, Parreira VF, Britto RR. Chest wall volumes during inspiratory loaded breathing in COPD patients. Respir Phys neurobiol. 2013;188(1):15-20.

10. Ricieri DV, Rosário Filho NA. Impacto de fatores externos sobra a mecânica respiratória avaliada por um modelo fotogramétrico específico: biofotogrametria. J Bras de Pneumol. 2008;34(9):702-6.

11. Ricieri DV, Rosário Filho NA. Efetividade de um modelo fotogramétrico para a análise da mecânica respiratória toracoabdominal na avaliação de manobras de isovolume em crianças. J Bras de Pneumol. 2009;35(2):144-50. 
12. Coelho LB, Brito JN. Fotogrametria Digital. Rio de Janeiro: EdUERJ; 2007.

13. Brito RR, Zampa CC, De Oliveira TA, Prado LF, Parreira VF. Effects of the aging process on respiratory function. Gerontology. 2009;55(5):505-10.

14. Ripka WL, Ulbricht L, Gewehr PM. Application of a photogrammetric kinematic model for prediction of lung volumes in adolescents: a pilot study. Biomed Eng Online. 2014;13(21):21-36.

15. Antunes LCO, Silva EG, Bocardo P, Daher DR, Faggiotto $\mathrm{RD}$, Rugolo LMSS. Efeitos da fisioterapia respiratória convencional versus aumento do fluxo expiratório na saturação de o2, freqüência cardíaca e freqüência respiratória, em prematuros no período pós-extubação. Rev Bras Fisioter. 2006;10(1):97-103.

16. Cavenaghi S, Moura SCG, Silva TH, Venturinelli TD, Marino LHC, Lamari NM. Importância da Fisioterapia no pré e pós-operatório de cirurgia pediátrica. Rev Bras Cir Cardiovasc. 2009;24(3):397-400.

17. Gasparetto S, Bussad VSR. Padrões e estados comportamentais de recém-nascidos durante o banho em maternidade: possibilidades de regulação e trocas sociais. Rev Bras Crescimento Desenvolv Hum. 2000;10(1):41-8.

18. Fontoura AL, Silveira MS, Almeida Jones MH. Aumento do fluxo expiratório produzido pelas técnicas de fisioterapia respiratória em lactentes. Sci Med. 2005;15(1):16-20.

19. Oliveira TRS, Santos CA, Viviani AG. Efeitos da fisioterapia respiratória em lactentes prematuros. Movimenta. 2013;6(2):456-62.

20. Sá FE, Frota LMCP, Oliveira IF, Bravo LG. Estudo sobre os efeitos fisiológicos da técnica de Aceleração do Fluxo expiratório lento em Prematuros. Rev Fisioter S Fun. 2012;1(1):16-21.

21. Luisi F. O papel da Fisioterapia respiratória na bronquilite viral aguda. Sci Med. 2008;18(1):39-44.

22. Castro G, Remondini R, Santos AZ, Prado C. Análise dos sintomas, sinais clínicos e suporte de oxigênio em pacientes com bronquiolite antes e após fisioterapia respiratória durante a internação hospitalar. Rev Paul Pediatr. 2011;29(4):599-605.
23. Gardengui G, Bertoldo KAM, Bonifácio JS, Corrêa EL, Miranda CC, Doria Filho U. Respostas hemodinâmicas e ventilatórias após fisioterapia em crianças com bronquilite viral aguda. Rev Eletr Saúde Ci. 2015;5(01):9-21.

24. Diniz NF, Gomes ELFD, Moran CA, Pereira SA, Martins LMA, Pereira LG. Assessment of the Effects of Manual Chest Compression Technique on Atelectasis in Infants: A Randomized Clinical Trial. Internat J Clinic Med. 2014;5(9):507-13.

25. Andrade LB, Silva KP, Apolinário EM, Moura CA, Lima MRO. Efeitos Cardiorrespiratórios da manobra de aceleração do fluxo expiratório em neonatos pré-termos em respiração espontânea. Rer Bras Fisiot. 2008; 12(2):62-3.

26. Jhonston C, Zanetti NM, Comaru T, Ribeiro SNS, Andrade LB, Santos SLL. I Recomendação Brasileira de Fisioterapia Respiratória em Unidade de terapia Intensiva Pediátrica e Neonatal. Rev Bras Ter Intensiva. 2012;24(2):119-29.

27. Gomes ELFD, Postiaux G, Medeiros DRL, Monteiro KKDS, Sampaio LMM, Costa, D. Cirurgia cardíaca pediátrica: o que esperar da intervenção fisioterapêutica? Rev Bras Cir Cardiovasc. 2012;26(2):241-7.

28. Pupin MK, Riccetto AGL, Ribeiro JD, Baracat ECE. Comparação dos efeitos de duas técnicas respiratórias em parâmetros cardiorrespiratórios de lactentes com brinquiolite viral aguda. J Bras Pneumol. 2009;35(9):860-7.

29. Arakaki VSNM, Oliveira AM, Bogossian T, Almeida VS, Silva GD, Ferreira HC. Importance of physiotherapy/ nursing multidisciplinary integration about update newborn position in the neonatal intensive care unit. Fisioter Mov. 2015;28(3):437-45.

30. Vasconcelos GAR, Almeida RCA, Bezerra AL. Repercussões da fisioterapia na unidade de terapia intensiva neonatal. Fisioter Mov. 2011;24(1):65-73.

Received in 04/20/2016

Recebido em 20/04/2016

Approved in 03/29/2017

Aprovado em 29/03/2017 